\title{
Farm Size, Cropping Pattern and Productivity Variation in Punjab: The Analysis of Mansa and Jalandhar Districts
}

\author{
${ }^{1}$ Jagdeep Singh, ${ }^{2}$ Hanuman Singh yadav \\ ${ }^{1}$ Research Scholar, Barkatullah University,Bhopal(M.P.) India. \\ ${ }^{2}$ Professor,Barkatullah University,Bhopal(M.P.) India.
}

\begin{abstract}
The present paper analyzes the trend and patterns of farm size, productivity and cropping pattern in districts of Mansa and Jalandhar. The results show that medium and large holdings are increasing in number over the time in both the districts. Increase in size of holdings coupled with other factors like increase in productivity in limited number of crops, minimum support price for wheat and rice as well as higher possibility of use of modern technology in wheat and rice cultivation has lead to wheat rice cycle. The other crops like cotton, maize, potato etc. are more popular among marginal and small farmers. It may be due to easy availability of family labour. Overall, the study points towards specialization in the cropping pattern, stagnation in productivity growth and increasing size of operational holdings.
\end{abstract}

KEYWORDS: Punjab; Jalandhar; Mansa; agriculture; cropping pattern.

\section{INTRODUCTION}

There is a long list of publications on relation between farm size and productivity. The debate started from the observation that productivity and farm size has an inverse relationship (see, Sen, 1962; Dantwala, 1961). Many arguments were provided to explain this phenomenon, among which most prominent is that extensive farming is done on small holdings due to availability of more family labour per unit of land (see, Berry 1979). Hence, the small farmers have higher the cropping intensity than the large farmers. On the other hand, large farmers suffer from increasing supervision cost as the size of land increases (Sanyal 1969). However, later studies found out that the difference in productivity between the small and large holdings decreased with green revolution, as mechanization helped the large farmers to manage their land at lower cost. Sen and Rudra (1980) reviewing the productivity debate came to the conclusion that modern technology has eroded the relationship between farm size and productivity. Punjab, being one of the beneficiaries of productivity increases during the green revolution, experienced fast mechanization as well as weakening of the land size and productivity relationship. In fact, the reversal of the trend was observed with the increase in modern technology and use of modern inputs in Punjab (Bajaj and Soni 1983). Though the positive relation between farm size and yield has been found in case of a few crops, especially rice (see, Bhalla and Chadha 1983), and other crops did not show any significant relationship, the high share of these crops made this change much more important.

The green revolution and resultant productivity increase benefited the farmers of Punjab by increasing the yield and allowing higher cropping intensity. Since, increase in productivity was also associated with reversal of the relationship between productivity and farm size, it made the large scale farming even more profitable. Nonetheless, these changes also results lead to change in some basic features of Punjab agriculture. One of the major problems faced by Punjab agriculture is the start of wheat rice cycle in Punjab. One of the major reasons is the increase in productivity of limited number of crops, especially rice (the other important reason being stable price for wheat and rice due to the presence of minimum support price). This resulted in complete ignorance of the crops other than wheat and rice. The other crop which was dominant was cotton, however, the loss of cotton crop for many consecutive years in second half of 1990s due to bollworm deteriorated the share of cotton crop in gross cultivated area and the trend in favor of rice cultivation became even stronger.

The higher productivity in large holdings also incentivized the farmers to increase size of holding, which is observed in the form of reverse tenancy in Punjab. The increase in holdings size further pushed the trend towards rice and wheat cultivation as these crops have higher possibility of use of modern technology. Thus, Punjab experienced two major changes due to productivity changes. First, the most of the gross cropped area was devoted to rice and wheat cultivation, and size of operational holdings has grown over time, which also means lower share of marginal and small holdings.

These changes have been also studied by many researchers, and a need for diversification in agriculture was stressed. Nonetheless, these changes are often studies at aggregate level, and micro level picture is limited to understand the conditions of marginal and small farmers. Also the cropping pattern, cropping intensity and holding size were not studied keeping in with different resources and possibilities available in different parts of Punjab. Moreover, there is hardly any study that provides a comprehensive view of nature of changes happening in latest years. These issues are very important for the complete understanding of the nature of changes in Punjab agriculture. To fill this gap present study compares tehsils of two districts, Mansa and Jallandhar. Mansa is one of most backward district as per Punjab (HDI), whereas Jalandhar is among developed regions. Also, the soil and climate conditions in Mansa pose constraints different from Jalandhar (the detail is discussed in different sections).

The study has following two objectives:

1. to understand trend and pattern in operational holding and agricultural infrastructure in two districts.

2. to analyze the change in cropping pattern in the light of changes in operational holdings and productivity.

For this purpose, data from various issues of Agriculture Census and Punjab Statistical Abstract is used. Section 1 of the paper discusses the trends in number area and size of operational holdings. The availability of sources of irrigation is analyzed in section 2. Section 3 and 4 examines the trends in yield, production and cropping pattern. And the last section concludes the study.

\section{TRENDS AND PATTERNS IN NUMBER, AREA AND SIZE OF OPERATIONAL HOLDINGS}


Share of Different Size Classes in Total Number of Operational Holdings

Table 1 shows tehsil-wise share of different size groups in number of operational holdings in district of Mansa during 2000-01. The share of medium size group (36.12 percent) is the highest among all groups, and share of marginal size holdings has the lowest among all classes. The majority of operational land holdings fall in semi medium or medium category, where the groups, semi medium and medium, together form about 65 percent of the total operational land holdings in all tehsils. Large size has approximately 10 percent of total share in all tehsils.

Table 1 Share of Different Size Groups in Number of Operational Holdings in District of Mansa in 2000-01 (in percentage)

\begin{tabular}{|c|c|c|c|c|}
\hline Size Group & Mansa & Budhlada & Sardulgarh & Mansa District \\
\hline Marginal & 9.12 & 8.54 & 9.48 & 9.05 \\
\hline Small & 12.88 & 14.82 & 15.86 & 14.3 \\
\hline Semi Medium & 30.73 & 29.59 & 29.71 & 30.01 \\
\hline Medium & 37.61 & 35.28 & 34.8 & 36.12 \\
\hline Large & 9.68 & 11.78 & 10.15 & 10.43 \\
\hline All Classes & 100 & 100 & 100 & 100 \\
\hline
\end{tabular}

Table 2 Number Of Operational Holdings by Size Group in 2005-06 in Mansa District (in percentage)

\begin{tabular}{|c|c|c|c|c|}
\hline Mansa & Mansa & Budhlada & Sardulgarh & Mansa District \\
\hline Marginal & 10.23 & 9.29 & 8.81 & 9.56 \\
\hline Small & 13.6 & 13.25 & 12.07 & 13.09 \\
\hline Semi Medium & 32.16 & 35.33 & 29.84 & 32.63 \\
\hline Medium & 36.07 & 34.14 & 37.44 & 35.77 \\
\hline Large & 7.95 & 7.98 & 11.85 & 8.95 \\
\hline All Classes & 100 & 100 & 100 & 100 \\
\hline
\end{tabular}

The same pattern in number of operational holdings continued in 2005-06 in tehsils of Mansa district (Table 2), where semi-medium and medium size class have the largest share among all classes. In comparison to 2000-01, shares of small and large classes in 200506 have declined slightly from 14.3 percent to 13.09 percent and 10.43 percent to 8.95 percent, respectively. There is 2.2 percent increase in the share of semi-medium and medium size classes during 2000-01 to 2005-06. In 2005-06, shares of marginal, small and semi-medium size class has increased but there is decreased in other classes. Semi-medium size class has shown larger increase from 2000-01 to 2005-06 in Budhlada tehsil compare to other classes. Share of semi-medium size class in Budhlada tehsil has increased from 29.59 percent in 2000-01 to 35.33 percent in 200506 . During the same period share of large size class declined from 11.78 to 7.98 in Budhlada tehsil. Sardulgarh tehsil has shown an opposite trend where share of semi-medium, medium and large has increased. Overall trend shows a shift towards medium size operational holdings, which means reduction in marginal and small holdings as well as large holdings. Though the decline in small and marginal holdings can be attributed to lower profits in those, the reasons for fall in share of large size holdings needs to be analyzed.

Table 3 Number Of Operational Holdings By Size Group During 2000-01in Jalandhar District (in percentage)

\begin{tabular}{|c|c|c|c|c|c|c|}
\hline Tehsil & Marginal & Small & Semi Medium & Medium & Large & Total Classes \\
\hline Jalandhar 1 & 28.32 & 17.84 & 29.31 & 19.53 & 5 & 100 \\
\hline Jalandhar ll & 29.09 & 17.08 & 29.33 & 20.03 & 4.48 & 100 \\
\hline Nakodar & 21.39 & 16.42 & 31.63 & 25.2 & 5.37 & 100 \\
\hline Phillaur & 24.04 & 14.57 & 26.98 & 25.96 & 8.45 & 100 \\
\hline Shahkot & 21.88 & 15.85 & 33.61 & 23.45 & 5.21 & 100 \\
\hline Jalandhar District & 25.09 & 16.21 & 29.88 & 22.95 & 5.87 & 100 \\
\hline
\end{tabular}

Table 3 shows number of operational holding by size groups during 2000-01 in Jalandhar district. In Jalandhar district, share of semimedium is the highest (29.88 percent) among all classes, whereas the large size class has lowest share which is 5.87 percent. Jalandher district had much higher percentage of marginal holdings the highest share of marginal farmers (29.9 percent) and Nakodar tehsil with 21.39 percent share has the lowest share among all tehsils. Share of large size class in Jalandhar district is quite low compare to tehsils of Mansa district. Phillaur tehsil is the only tehsil which has the share of large holdings ( 8.45 percent) that is comparable to Mansa district.

compared to Mansa districts. Within the district, Jalandhar-ll has

Table 4 Number of Operational Holdings By Size Group in Jalandhar District during 2005-06

\begin{tabular}{|c|c|c|c|c|c|c|}
\hline Tehsil & Marginal & Small & Semi Medium & Medium & Large & Total Classes \\
\hline Jalandhar 1 & 11.08 & 19.13 & 35.77 & 27.07 & 6.95 & 100 \\
\hline Jalandhar 11 & 12.62 & 18.94 & 32.83 & 29.22 & 6.39 & 100 \\
\hline Nakodar & 5.58 & 13.74 & 27.84 & 39.18 & 13.66 & 100 \\
\hline Phillaur & 7.63 & 12.21 & 31.41 & 35.72 & 13.02 & 100 \\
\hline
\end{tabular}




\begin{tabular}{|c|c|c|c|c|c|}
\hline Shahkot & 7.67 & 17.75 & 33.46 & 100 & 32.46 \\
\hline Jalandhar District & 8.94 & 16.09 & 32.23 & 32.75 & 9.9 \\
\hline
\end{tabular}

Contrary to the trend in Mansa district, Jalandher district shows a significant change in pattern of operational holdings (Table 4). The data shows that share of marginal size class declined from 25.09 percent to 8.94 percent between 2000-01 and 2005-06. During the same period, the share of large class has increased from 5.87 to 9.90 percent. Only small operational holdings did not show any significant change. Reason behind this change may be increase in operating cost in marginal farmers, which may have result into shift of significant portion of marginal and small farmers out of agriculture sector. The decline in marginal operational holdings is shown in increase in share of medium and large farmers. Two tehsils, Nakodar and Phillaur experienced largest increase in
Medium and large operational holding, where the two size classes make about 50 percent of the total land holdings in 2005-06.

Share of Different Size Classes in Total Area Operated

The previous sub-section has shown that the two districts, Mansa and Jalandhar, differ considerably in their distribution of operational holdings among different size classes. While Jalandhar had significant number of marginal and small holdings in 2000-01, Mansa had much lower share of these two size classes. However, the earlier analysis does not tell us about the significance of different classes as well as the extent of disparities that exist among different size classes. To understand their relative importance and extent of disparities, there is a need to discuss the distribution of area operated among different size classes.

Table 5 Tehsil-wise Share of Different Size Groups in Total Operated Area in Mansa District in 2000-01

\begin{tabular}{|c|c|c|c|c|}
\hline Size Group & Sardulgarh & Mansa & Budladgha \\
\hline Marginal & 1.2 & 1.22 & 1.06 \\
\hline Small & 4.64 & 3.9 & 4.25 \\
\hline Semi medium & 17.66 & 17.85 & 16.06 & 4.22 \\
\hline Medium & 44.29 & 47.75 & 37.36 \\
\hline Large & 32.21 & 29.28 & 17.25 \\
\hline All Classes & 100 & 100 & 34.81 \\
\hline
\end{tabular}

The data on tehsil-wise share of different size groups in total operated area in district of Mansa during 2000-01 shows that medium and large farmers, which makes about 46 percent of operational holdings, controlled more than three-fourth of the operated area (Table 5). If semi medium class is also included in the two groups, the total operated area controlled by classes other than marginal and small was almost 95 percent. The marginal and small farmers, which made about 25 percent of the operational holdings, were cultivating just about 5.4 percent of the operated land. Among the three tehsils, share of area operated by large farmers is relatively less in Mansa tehsils (29.28 percent), and the largest in Budladha (37.28 percent). The share of marginal and small holdings is also the lowest in Mansa tehsil, though the difference among tehsils is not noteworthy.

Table 6 points out towards similar pattern in 2005-06 in the district of Mansa. Nonetheless, Mansa tehsils shows a small change from the previous year in the form of about one percent increase in the share of area operated by marginal and small farmers. Though the increase is not considerable, the trend is important because it happened despite decline in their share in number of total operational holdings during the same period. This gain in share of area operated by marginal and small holders has come at cost of large farmers, which showed a decline of about 3 percent in their share. During the same period, share of large size class in Budhlada tehsil also declined from 37.28 percent in $2000-01$ to 28.4 percent in 2005-06 recording approximately 9 percent decline. Though, the decline is much larger in case of Budladha tehsil compared to Mansa tehsil, the increase of share in Budladha is larger in medium and semi medium size class and relatively lesser gains are observed for marginal and small size holders. Sardulgarh tehsil, on the contrary, shows an increase in the share of large farmers largely at the cost of small and semi medium category.

Table 6 Tehsil-wise Share of Different Size Groups in Total Operated Area in Mansa District in 2005-06

\begin{tabular}{|c|c|c|c|c|}
\hline Size Group & Sardulgarh & Mansa & Budladgha & Mansa District \\
\hline Marginal & 1.20 & 1.69 & 1.54 & 1.50 \\
\hline Small & 3.54 & 4.46 & 4.48 & 4.21 \\
\hline Semi medium & 16.55 & 19.86 & 21.44 & 19.44 \\
\hline Medium & 44.35 & 47.81 & 44.14 & 45.66 \\
\hline Large & 34.35 & 26.19 & 28.4 & 29.19 \\
\hline All Classes & 100 & 100 & 100 & 100 \\
\hline
\end{tabular}

Table 7 Tehsil-wise Share of Different Size Groups in Total Operated Area in Jalandhar District in 2000-01

\begin{tabular}{|c|c|c|c|c|c|c|}
\hline Size Group & Jalandhar District & Jalandhar I & Jalandhar II & Nakodar & Phillaur & Shahkot \\
\hline Marginal & 5.41 & 6.55 & 6.98 & 4.55 & 4.52 & 4.95 \\
\hline Small & 7.04 & 8.28 & 8.39 & 6.91 & 5.57 & 7.03 \\
\hline Semi Medium & 23.40 & 25.13 & 25.61 & 23.78 & 18.68 & 26.84 \\
\hline Medium & 37.82 & 34.87 & 36.74 & 40.24 & 38.21 & 38.50 \\
\hline Large & 26.33 & 25.17 & 22.27 & 24.51 & 33.02 & 22.68 \\
\hline
\end{tabular}




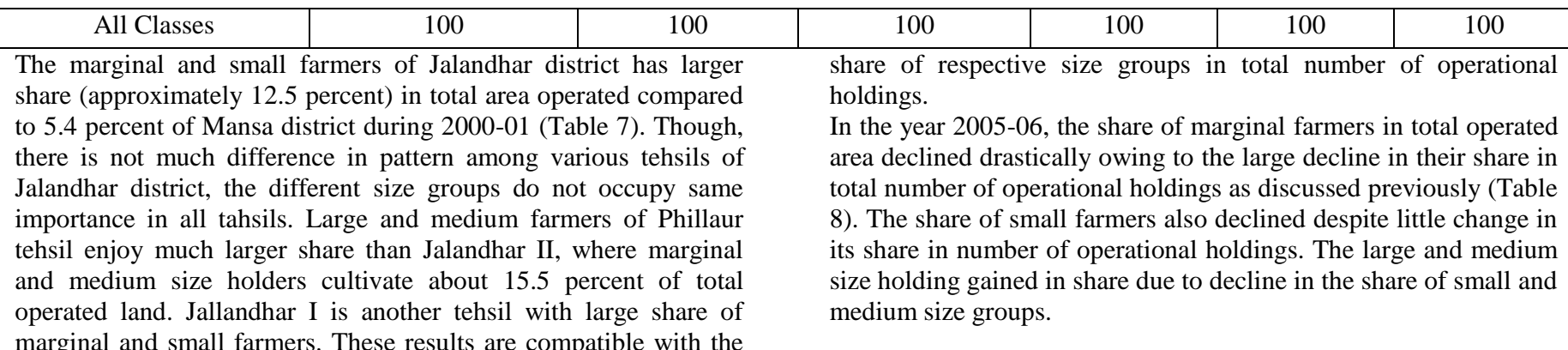
marginal and small farmers. These results are compatible with the

Table 8 Tehsil-wise Share of Different Size Groups in Total Operated Area in Jalandhar District in 2005-06

\begin{tabular}{|c|c|c|c|c|c|c|}
\hline Size Group & Jalandhar District & Jalandhar I & Jalandhar II & Nakodar & Phillaur & Shahkot \\
\hline Marginal & 1.33 & 1.84 & 2.2 & 0.77 & 1 & 1.23 \\
\hline Small & 4.93 & 6.69 & 6.96 & 3.54 & 3.36 & 5.67 \\
\hline Semi Medium & 18.58 & 24 & 22.45 & 13.45 & 16.32 & 19.88 \\
\hline Medium & 41.45 & 39.19 & 43.55 & 41.61 & 40.69 & 42.12 \\
\hline Large & 33.72 & 28.27 & 24.85 & 40.63 & 38.63 & 31.1 \\
\hline All Classes & 100 & 100 & 100 & 100 & 100 & 100 \\
\hline
\end{tabular}

Average size of Operational Holdings of Different Size Groups Though, the share of various size groups in number of operational holdings and total area operated provides us information on disparities among different groups. Therefore, the average size of holdings is compared for both Mansa and Jalandhar districts.

Table 9 Tehsil-wise Average Area Operated by Size Groups in Mansa District in 2000-01 (in Hectare)

\begin{tabular}{|c|c|c|c|c|}
\hline Size Group & Sardulgarh & Mansa & Budladgha & Mansa District \\
\hline Marginal & 0.6 & 0.62 & 0.61 & 0.61 \\
\hline Small & 1.38 & 1.41 & 1.41 & 1.4 \\
\hline Semi Medium & 2.8 & 2.7 & 2.66 & 2.72 \\
\hline Medium & 6 & 5.89 & 5.75 & 5.88 \\
\hline Large & 14.96 & 14.07 & 15.53 & 14.8 \\
\hline All Classes & 4.71 & 4.64 & 4.91 & 4.74 \\
\hline
\end{tabular}

Table 9 provides tehsil-wise average area operated by size groups in Mansa in 2000-01. The tehsils of Mansa district are similar to each other in relation to average size of holdings. The average size of holdings in tehsils of Mansa district varies between 4.64 hectare and 4.91 hectare, with 4.74 hectare average size of holding for
Mansa district. The average size of holding of marginal, small, semi-medium, medium and large holdings for Mansa district are 0.61 hectare, 1.4 hectare, 2.72 hectare, 5.88 hectare and 14.8 hectare, respectively.

Table 10 Tehsil-wise Average Area Operated by Size Groups in Mansa District in 2005-06 (in Hectare)

\begin{tabular}{|c|c|c|c|c|}
\hline Size Group & Sardulgarh & Mansa & Budladgha & Mansa District \\
\hline Marginal & 0.67 & 0.71 & 0.71 & 0.7 \\
\hline Small & 1.44 & 1.41 & 1.44 & 1.43 \\
\hline Semi Medium & 2.72 & 2.65 & 2.59 & 2.64 \\
\hline Medium & 5.8 & 5.69 & 5.52 & 5.66 \\
\hline Large & 14.2 & 14.14 & 15.18 & 14.47 \\
\hline All Classes & 4.89 & 4.29 & 4.27 & 4.44 \\
\hline
\end{tabular}

The average size of holding remained almost same in Mansa district during 2005-06 (Table 10). The minor change that happened during this period is a slight increase in average size of marginal holdings from 0.61 hectare to 0.7 hectare, and decline in average area of semi-medium, medium and large holdings. The average area operated of Mansa district also declined from 4.74 hectare to 4.44 hectare. The increase in size of marginal holdings might be the result of shift of marginal farmers out of agriculture sector.

Table 11 Average Size of Operational Holdings by Size Group in Jalandhar District during 2000-01 (in Hectare)

Table 11 Average Size of Operational Holdings by Size Group in Jalandhar District during 2000-01 (in Hectare)
\begin{tabular}{|c|c|c|c|c|c|c|}
\hline Tehsil & Marginal & Small & Semi Medium & Medium & Large & All Classes \\
\hline Jalandhar 1 & 0.74 & 1.49 & 2.75 & 5.72 & 16.12 & 3.2 \\
\hline Jalandhar ll & 0.73 & 1.5 & 2.67 & 5.61 & 15.2 & 3.06 \\
\hline
\end{tabular}




\begin{tabular}{|c|c|c|c|c|c|c|}
\hline Nakodar & 0.77 & 1.53 & 2.72 & 5.79 & 16.54 & 3.62 \\
\hline Phillaur & 0.75 & 1.52 & 2.75 & 5.85 & 15.53 & 3.98 \\
\hline Shahkot & 0.76 & 1.5 & 2.7 & 5.55 & 14.71 & 3.38 \\
\hline Jalandhar District & 0.75 & 1.51 & 2.72 & 5.71 & 15.56 & 3.47 \\
\hline
\end{tabular}

Table 11 shows average size of operational holdings by size group during 2000-01 in Jalandhar district. The average size of holding is not much different in Jalandhar district than Mansa district except that the average size of operational holding is a little larger for marginal, small and large size classes in Jalandhar. It might be due to higher probability of farmers with very small holdings to leave agriculture, and higher likelihood of large farmers to lease in land (however the reason needs verification which is not possible with the data from the present resource). The tehsils of the Jalandhar

district are also highly similar as per as the average size of holding is concerned. Nonetheless, Jalandhar district on average had lower size of holding (3.47 hectare) in 2000-01 compared to Mansa district in the same year (4.74 hectare) owing to the larger of marginal and small farmers in Jalandhar district.. Here, Jallandhar II has the smallest size of holding (3.06 hectare) among all tehsils, whereas Phillaur has the largest average size of holding (approximately 4 hectare).

Table 12 Average Size of Operational Holdings By Size Group during 2005-06 in Jalandhar District (in Hectare)

\begin{tabular}{|c|c|c|c|c|c|c|}
\hline Tehsil & Marginal & Small & Semi Medium & Medium & Large & All Classes \\
\hline Jalandhar 1 & 0.65 & 1.37 & 2.63 & 5.67 & 15.93 & 3.92 \\
\hline Jalandhar ll & 0.66 & 1.39 & 2.59 & 5.64 & 14.7 & 3.78 \\
\hline Nakodar & 0.74 & 1.39 & 2.61 & 5.73 & 16.06 & 5.4 \\
\hline Phillaur & 0.98 & 1.43 & 2.7 & 5.93 & 15.43 & 5.2 \\
\hline Shahkot & 0.7 & 1.4 & 2.61 & 5.71 & 15.6 & 4.39 \\
\hline Jalandhar District & 0.68 & 1.4 & 2.63 & 5.76 & 15.55 & 4.56 \\
\hline
\end{tabular}

Table 12 indicates small decline in average size of holding for marginal and small group in 2005-06 for Jalandhar district. Phillaur is the only tehsil with increase in average size of operational holding for marginal farmers from 0.75 hectare to 0.98 hectare. The combined average size of operational holding of all classes in Jalandhar district has increased from 3.47 hectare to 4.56 hectare between 2000-01 and 2005-06, which is comparable to Mansa district. This increase happened for all the tehsils in the district. Jalandhar II, though still has the lowest average holding size, increased its average holding size from 3.06 hectare in 2000-01 to 3.78 hectare in 2005-06, and Phillaur continuing with the highest average size of holding improved its holding size from 3.98 hectare in 2000-01 to 5.4 hectare in 2005-06. The main reason for the improvement in average size of holding despite class wise average size remained same is decline in share of marginal and small holdings, which increase the weight of medium and large size holdings in the average.

The above discussion points out that Jalandhar and Mansa district have significant difference in the share of different size classes in number and area of operational holdings. In addition, the two districts are also showing change in the patterns over the years. Jalandhar especially has shows a significant change in share of marginal farmers and average size of holding. Nonetheless, the trends and patterns in number and area of operational holdings provide a part of the picture, and one also needs to know the resources available to the famers to have a complete picture of agriculture scenario. Punjab is known for high level of irrigated area, nonetheless each area has its own features and source of irrigation may differ according to the region. The next section will try to understand the trends and patterns in source of irrigation to provide a complete picture of available resources and opportunities in the two districts.

\section{TREND AND PATTERNS IN SOURCE OF IRRIGATION}

Major Source of Irrigation

Table 13 provides information on source of irrigation in Mansa district in 1995-96. Mansa district shows high dependency on canal water, and about three-fourth of the area (73.56 percent) is irrigated by canal water. Remaining one-fourth (26.4 percent) area is irrigated with tubewell water. The use of other sources, like rainwater, ponds etc., is negligible. Another important feature of the pattern is that the share of tubewell water increases with increase in size of holding for tehsils Mansa and Budhladha with Sardulgarh showing opposite trend. One of the reasons for this trend may be larger area under paddy cultivation in tehsils Mansa and Budhladha (see, the cropping pattern in next section), and higher water consumption might have motivated the large farmers to invest in tubewells. As a result, large farmers despite having higher access to canal water might have larger share of tubewell irrigated land. On the other hand, Sardulgarh has much less area under paddy cultivation, hence the results points out towards possible higher access of the canal water to large resources. Overall the share of canal irrigation is the highest in Mansa tehsil followed by Sardulgarh and Budhladha. The pattern is mostly the mixed result of cropping pattern and availability of canal water, the detailed understudying requires a separate study and is out of the scope of the present one

Table 13 Area Irrigated by Different Sources of Irrigation in Mansa District in 1995-96 (in Percentage).

\begin{tabular}{|c|c|c|c|c|c|c|c|}
\hline Tehsil & Sources & Marginal & Small & Semi Medium & Medium & Large & All Classes \\
\hline \multirow{3}{*}{ Mansa } & Canals & 78.45 & 75.91 & 67.62 & 62.24 & 67.93 & 65.56 \\
\cline { 2 - 9 } & Tubewells & 21.55 & 24.09 & 32.38 & 37.67 & 32.07 & 34.40 \\
\cline { 2 - 9 } & Other & 0.00 & 0.00 & 0.00 & 0.09 & 0.00 & 0.04 \\
\hline
\end{tabular}




\begin{tabular}{|c|c|c|c|c|c|c|c|}
\hline & Total & 100 & 100 & 100 & 100 & 100 & 100 \\
\hline \multirow{4}{*}{ Budhlada } & Canals & 87.62 & 93.71 & 82.50 & 83.45 & 80.52 & 82.59 \\
\hline & Tubewells & 12.38 & 6.29 & 17.38 & 16.54 & 19.48 & 17.39 \\
\hline & Other & 0.00 & 0.00 & 0.13 & 0.01 & 0.00 & 0.01 \\
\hline & Total & 100 & 100 & 100 & 100 & 100 & 100 \\
\hline \multirow{4}{*}{ Sardulhgarh } & Canals & 71.02 & 77.36 & 74.50 & 73.86 & 76.84 & 75.05 \\
\hline & Tubewells & 28.80 & 22.64 & 25.50 & 26.14 & 22.95 & 24.88 \\
\hline & Other & 0.18 & 0.00 & 0.00 & 0.00 & 0.21 & 0.07 \\
\hline & Total & 100 & 100 & 100 & 100 & 100 & 100 \\
\hline \multirow{4}{*}{$\begin{array}{l}\text { Mansa } \\
\text { District }\end{array}$} & Canals & 81.89 & 82.85 & 74.01 & 71.09 & 75.06 & 73.56 \\
\hline & Tubewells & 18.07 & 17.15 & 25.95 & 28.87 & 24.90 & 26.40 \\
\hline & Other & 0.04 & 0.00 & 0.04 & 0.04 & 0.04 & 0.04 \\
\hline & Total & 100 & 100 & 100 & 100 & 100 & 100 \\
\hline
\end{tabular}

Table 14 Area Irrigated By Different Sources in Mansa District in 2005-06 (in Percentage)

\begin{tabular}{|c|c|c|c|c|c|c|c|}
\hline Tehsil & Sources & Marginal & Small & Semi Medium & Medium & Large & All Classes \\
\hline \multirow{4}{*}{ Mansa } & Canals & 70.59 & 59.66 & 53.22 & 52.90 & 45.72 & 51.66 \\
\hline & Tubewells & 29.17 & 40.28 & 46.58 & 46.86 & 54.19 & 48.11 \\
\hline & Other & 0.24 & 0.06 & 0.20 & 0.24 & 0.09 & 0.22 \\
\hline & Total & 100 & 100 & 100 & 100 & 100 & 100 \\
\hline \multirow{4}{*}{ Budhlada } & Canals & 89.85 & 90.30 & 86.09 & 86.92 & 96.48 & 89.65 \\
\hline & Tubewells & 10.15 & 9.70 & 13.82 & 12.98 & 3.52 & 10.29 \\
\hline & Other & 0.00 & 0.00 & 0.09 & 0.10 & 0.00 & 0.06 \\
\hline & Total & 100 & 100 & 100 & 100 & 100 & 100 \\
\hline \multirow{4}{*}{ Sardulhgarh } & Canals & 75.20 & 70.99 & 74.81 & 75.45 & 76.92 & 75.68 \\
\hline & Tubewells & 24.80 & 28.90 & 25.06 & 24.45 & 23.02 & 24.24 \\
\hline & Other & 0.00 & 0.11 & 0.13 & 0.10 & 0.06 & 0.09 \\
\hline & Total & 100 & 100 & 100 & 100 & 100 & 100 \\
\hline \multirow{4}{*}{$\begin{array}{l}\text { Mansa } \\
\text { District }\end{array}$} & Canals & 77.93 & 72.81 & 70.00 & 69.56 & 71.89 & 70.58 \\
\hline & Tubewells & 21.96 & 27.14 & 29.86 & 30.28 & 28.05 & 29.29 \\
\hline & Other & 0.11 & 0.05 & 0.14 & 0.16 & 0.05 & 0.13 \\
\hline & Total & 100 & 100 & 100 & 100 & 100 & 100 \\
\hline
\end{tabular}

There is significant change in the share of sources of irrigation in Mansa (tehsil) and Budhlada between 1995-96 and 2005-06 (see, Table 14). The share of tubewells increased from 34 percent to 48 percent in Mansa (tehsil) declined from 17 percent to 10 percent in

Budhladha. The Share remained almost same in Sardulgarh. Another change that can be seen is the reversal of pattern in source of irrigation for Budhlada, i.e. share of tubewells decreases with increase in land size.

Table 15 Area Irrigated By Different Sources in Jalandhar District in 1995-96 (in Percentage)

\begin{tabular}{|c|c|c|c|c|c|c|c|}
\hline Tehsil & Sources & Marginal & Small & Semi Medium & Medium & Large & Total Classes \\
\hline \multirow{4}{*}{ Jalandhar 1} & Canals & 0.07 & 0.61 & 0.82 & 2.32 & 3.81 & 2.13 \\
\hline & Tubewells & 99.50 & 99.25 & 99.18 & 97.43 & 96.19 & 97.75 \\
\hline & Other & 0.43 & 0.15 & 0.00 & 0.25 & 0.00 & 0.12 \\
\hline & Total & 100 & 100 & 100 & 100 & 100 & 100 \\
\hline \multirow{4}{*}{ jalandhar 11} & Canals & 0.51 & 1.39 & 1.51 & 1.79 & 1.59 & 1.52 \\
\hline & Tubewells & 99.28 & 98.61 & 98.31 & 98.00 & 85.79 & 95.14 \\
\hline & Other & 0.22 & 0.00 & 0.19 & 0.22 & 12.62 & 3.34 \\
\hline & Total & 100 & 100 & 100 & 100 & 100 & 100 \\
\hline \multirow{2}{*}{ Nakoddar } & Canals & 0.00 & 0.00 & 0.18 & 0.24 & 0.90 & 0.37 \\
\hline & Tubewells & 99.73 & 98.55 & 99.42 & 99.76 & 99.09 & 99.49 \\
\hline
\end{tabular}




\begin{tabular}{|c|c|c|c|c|c|c|c|}
\hline & Other & 0.27 & 1.45 & 0.39 & 0.01 & 0.01 & 0.14 \\
\hline & Total & 100 & 100 & 100 & 100 & 100 & 100 \\
\hline \multirow{4}{*}{ Phillaur } & Canals & 2.66 & 3.83 & 2.83 & 3.35 & 3.01 & 3.15 \\
\hline & Tubewells & 97.18 & 96.14 & 97.04 & 96.65 & 96.99 & 96.82 \\
\hline & Other & 0.16 & 0.03 & 0.13 & 0.00 & 0.00 & 0.03 \\
\hline & Total & 100 & 100 & 100 & 100 & 100 & 100 \\
\hline \multirow{4}{*}{ Shahkot } & Canals & 0.00 & 0.60 & 0.10 & 0.00 & 0.00 & 0.05 \\
\hline & Tubewells & 99.48 & 95.92 & 97.81 & 95.72 & 94.50 & 96.22 \\
\hline & Other & 0.52 & 3.47 & 2.09 & 4.28 & 5.50 & 3.72 \\
\hline & Total & 100 & 100 & 100 & 100 & 100 & 100 \\
\hline \multirow{4}{*}{$\begin{array}{c}\text { Jalandhar } \\
\text { District }\end{array}$} & Canals & 0.61 & 1.63 & 1.22 & 1.66 & 2.28 & 1.66 \\
\hline & Tubewells & 99.06 & 97.72 & 98.27 & 97.38 & 95.30 & 97.16 \\
\hline & Other & 0.32 & 0.65 & 0.51 & 0.95 & 2.42 & 1.18 \\
\hline & Total & 100 & 100 & 100 & 100 & 100 & 100 \\
\hline
\end{tabular}

Source: Government of India (2001)

Jalandhar presents a totally different pattern of the source of irrigation, where more than 97 percent of the irrigation depends on tubewell (Table 15). Barring Phillaur, the area under canal irrigation is not only much less (around 1.66 percent), but also mainly confined to medium and large holdings. Despite Phillaur showing the availability of canal water to marginal and small

farmers, the lower availability of canal water in the region has constrained their access to it. The share of other sources is relatively higher with its significant share in Shahkot and Jalandhar II with higher level of use of other sources by medium and large farmers.

Table 16 Area Irrigated By Different Sources in Jalandhar District in 2005-06 (in Percentage)

\begin{tabular}{|c|c|c|c|c|c|c|c|}
\hline Tehsil & Sources & Marginal & Small & Semi Medium & Medium & Large & Total Classes \\
\hline \multirow{4}{*}{ Jalandhar 1} & Canals & 1.42 & 1.17 & 1.26 & 4.32 & 4.42 & 3.35 \\
\hline & Tubewells & 86.59 & 97.55 & 98.38 & 95.32 & 95.58 & 96.11 \\
\hline & Other & 11.99 & 1.28 & 0.36 & 0.36 & 0.00 & 0.53 \\
\hline & Total & 100 & 100 & 100 & 100 & 100 & 100 \\
\hline \multirow{4}{*}{ Jalandhar 11} & Canals & 0.00 & 0.44 & 0.44 & 0.50 & 1.29 & 0.67 \\
\hline & Tubewells & 99.24 & 99.56 & 99.56 & 99.50 & 98.71 & 99.32 \\
\hline & Other & 0.76 & 0.00 & 0.00 & 0.01 & 0.00 & 0.02 \\
\hline & Total & 100 & 100 & 100 & 100 & 100 & 100 \\
\hline \multirow{4}{*}{ Nakoddar } & Canals & 0.00 & 0.00 & 0.53 & 0.41 & 1.08 & 0.68 \\
\hline & Tubewells & 100.00 & 99.40 & 98.70 & 99.59 & 98.92 & 99.19 \\
\hline & Other & 0.00 & 0.60 & 0.77 & 0.00 & 0.00 & 0.12 \\
\hline & Total & 100 & 100 & 100 & 100 & 100 & 100 \\
\hline \multirow{4}{*}{ Phillaur } & Canals & 0.49 & 1.02 & 1.11 & 0.95 & 0.92 & 0.96 \\
\hline & Tubewells & 99.51 & 98.98 & 98.82 & 98.94 & 99.08 & 98.98 \\
\hline & Other & 0.00 & 0.00 & 0.08 & 0.11 & 0.00 & 0.06 \\
\hline & Total & 100 & 100 & 100 & 100 & 100 & 100 \\
\hline \multirow{4}{*}{ Shahkot } & Canals & 0.00 & 0.00 & 0.00 & 0.25 & 0.49 & 0.26 \\
\hline & Tubewells & 100.00 & 100.00 & 99.69 & 99.28 & 98.99 & 99.32 \\
\hline & Other & 0.00 & 0.00 & 0.31 & 0.47 & 0.52 & 0.43 \\
\hline & Total & 100 & 100 & 100 & 100 & 100 & 100 \\
\hline \multirow{3}{*}{$\begin{array}{c}\text { Jalandhar } \\
\text { District }\end{array}$} & Canals & 0.38 & 0.54 & 0.69 & 1.06 & 1.32 & 1.04 \\
\hline & Tubewells & 97.17 & 99.15 & 99.06 & 98.77 & 98.59 & 98.76 \\
\hline & Other & 2.45 & 0.31 & 0.25 & 0.17 & 0.09 & 0.20 \\
\hline
\end{tabular}




\begin{tabular}{|c|c|c|c|}
\hline & Total & 100 & 100 \\
\hline
\end{tabular}

Table 16 shows that the similar pattern continued in 2005-06. A few minor changes that happened in the form of decline in share of canal and other sources are not significant. Only significant change observed is high share of other sources of irrigation for marginal farmers (about 12 percent) in Jalandhar I. It might be due to large decline in number of marginal holdings, where the farmers that could lease out their land at advantageous terms might be those with tubewells or canal irrigated land. Another possible reason is shift of cropping pattern for that category. However, there is need of micro level study to understand the actual reasons.

Trends and Patterns in Source of Energy for Tubewells

The previous subsection showed that tubewells are the most important source of irrigation in both the districts. The present subsection analyzes the source of the power for tubewell pump sets.

\begin{tabular}{|l|l|l|l}
100 & 100 & 100 & 100 \\
\hline
\end{tabular}

People use either electric or diesel to power their pump sets. The distribution of diesel or electricity tubewells is not same for all size classes. The distribution becomes important due to lower running cost of electric tubewells as electricity is provided for free to the farmers in Punjab. In fact, Punjab Table 17 shows that marginal and small farmers in district Mansa have lower access to electric tubewells in 1995-96. Sardulgarh is the only exception to the rule, where marginal and small farmers also have high access to electric tubewells, and it is semi-medium and medium farmers that have relatively high dependency on diesel pumps. On average, 17 percent of the farmers have use electric pump sets in Mansa district, which Budhlada having comparatively lower share of electric pump sets (12.53 percent compared to above 19 percent in other tehsils).

Table 17 Percentage of Electric and Diesel Tube wells By Size Classes in Mansa District in 1995-96

\begin{tabular}{|c|c|c|c|c|c|c|c|}
\hline Tehsil/ District & Pump Sets & Marginal & Small & Semi Medium & Medium & Large & $\begin{array}{c}\text { Total } \\
\text { Classes } \\
\end{array}$ \\
\hline \multirow[b]{3}{*}{ Mansa } & Electric & 13.72 & 7.65 & 12.95 & 23.22 & 30.51 & 19.20 \\
\hline & Diesel & 86.28 & 92.35 & 87.05 & 76.78 & 69.49 & 80.80 \\
\hline & Total & 100 & 100 & 100 & 100 & 100 & 100 \\
\hline \multirow[b]{3}{*}{ Budhlada } & Electric & 9.77 & 5.68 & 6.98 & 12.67 & 25.79 & 12.53 \\
\hline & Diesel & 90.23 & 94.32 & 93.02 & 87.33 & 74.21 & 87.47 \\
\hline & Total & 100 & 100 & 100 & 100 & 100 & 100 \\
\hline \multirow[b]{3}{*}{ Sardulgarh } & Electric & 32.50 & 32.46 & 8.09 & 14.47 & 36.75 & 19.61 \\
\hline & Diesel & 67.50 & 67.54 & 91.91 & 85.53 & 63.25 & 80.39 \\
\hline & Total & 100 & 100 & 100 & 100 & 100 & 100 \\
\hline \multirow{3}{*}{$\begin{array}{l}\text { Mansa } \\
\text { District }\end{array}$} & Electric & 18.81 & 11.04 & 10.12 & 18.33 & 29.87 & 17.01 \\
\hline & Diesel & 81.19 & 88.96 & 89.88 & 81.67 & 70.13 & 82.99 \\
\hline & Total & 100 & 100 & 100 & 100 & 100 & 100 \\
\hline
\end{tabular}

Source: Government of India (1996)

Table 18 Percentage of Electric and Diesel Tube wells By Size Classes in Mansa District in 2005-06

\begin{tabular}{|c|c|c|c|c|c|c|c|}
\hline Tehsil & Pump Sets & Marginal & Small & Semi Medium & Medium & Large & Total Classes \\
\hline \multirow{3}{*}{ Mansa } & Electric & 9.47 & 16.21 & 24.14 & 30.11 & 40.20 & 28.15 \\
\hline & Diesel & 90.53 & 83.79 & 75.86 & 69.89 & 59.80 & 71.85 \\
\hline & Total & 100 & 100 & 100 & 100 & 100 & 100 \\
\hline \multirow{3}{*}{ Budhlada } & Electric & 3.22 & 4.91 & 9.98 & 24.00 & 30.55 & 19.86 \\
\hline & Diesel & 96.78 & 95.09 & 90.02 & 76.00 & 69.45 & 80.14 \\
\hline & Total & 100 & 100 & 100 & 100 & 100 & 100 \\
\hline \multirow{3}{*}{ Sardulgarh } & Electric & 1.25 & 3.62 & 17.42 & 25.59 & 28.35 & 21.66 \\
\hline & Diesel & 98.75 & 96.38 & 82.58 & 74.41 & 71.65 & 78.34 \\
\hline & Total & 100 & 100 & 100 & 100 & 100 & 100 \\
\hline \multirow{3}{*}{ Mansa District } & Electric & 6.41 & 10.14 & 18.67 & 27.39 & 33.82 & 24.26 \\
\hline & Diesel & 93.59 & 89.86 & 81.33 & 72.61 & 66.18 & 75.74 \\
\hline & Total & 100 & 100 & 100 & 100 & 100 & 100 \\
\hline
\end{tabular}

Source: Government of India (2006)

The percentage of electric pump sets increased from about 17 percent to 24.26 percent in Mansa district in 2005-06 (Table 18). However, the improvement in percentage of electric pumps has 60 percent), and marginal and small farmers showed a decline in their share. The reason for this shift is not clear from the table and needs further investigation.

happened for medium and large farmers (from about 50 percent to

Table 19. Percentage of Electric and Diesel Tube wells By Size Classes in Jalandhar District in 1995-96 


\begin{tabular}{|c|c|c|c|c|c|c|c|}
\hline Tehsil & Pump Sets & Marginal & Small & Semi Medium & Medium & Large & Total Classes \\
\hline \multirow[b]{3}{*}{ Jalandhar 1} & Electric & 60.88 & 73.91 & 80.19 & 83.46 & 84.07 & 77.27 \\
\hline & Diesel & 39.12 & 26.09 & 19.81 & 16.54 & 15.93 & 22.73 \\
\hline & Total & 100 & 100 & 100 & 100 & 100 & 100 \\
\hline \multirow[b]{3}{*}{ Jalandhar 11} & Electric & 59.95 & 73.32 & 79.71 & 83.88 & 82.71 & 75.69 \\
\hline & Diesel & 40.05 & 26.68 & 20.29 & 16.12 & 17.29 & 24.31 \\
\hline & Total & 100 & 100 & 100 & 100 & 100 & 100 \\
\hline \multirow[b]{3}{*}{ Nakoddar } & Electric & 57.26 & 69.71 & 80.88 & 88.32 & 90.68 & 78.82 \\
\hline & Diesel & 42.74 & 30.29 & 19.12 & 11.68 & 9.32 & 21.18 \\
\hline & Total & 100 & 100 & 100 & 100 & 100 & 100 \\
\hline \multirow[b]{3}{*}{ Shahkot } & Electric & 55.11 & 69.44 & 74.22 & 66.79 & 67.47 & 67.33 \\
\hline & Diesel & 44.89 & 30.56 & 25.78 & 33.21 & 32.53 & 32.67 \\
\hline & Total & 100 & 100 & 100 & 100 & 100 & 100 \\
\hline \multirow[b]{3}{*}{ Phillaur } & Electric & 57.54 & 62.92 & 74.03 & 72.12 & 74.33 & 70.00 \\
\hline & Diesel & 42.46 & 37.08 & 25.97 & 27.88 & 25.67 & 30.00 \\
\hline & Total & 100 & 100 & 100 & 100 & 100 & 100 \\
\hline \multirow{3}{*}{$\begin{array}{c}\text { Jalandhar } \\
\text { District }\end{array}$} & Electric & 58.23 & 69.46 & 77.15 & 74.87 & 75.89 & 72.52 \\
\hline & Diesel & 41.77 & 30.54 & 22.85 & 25.13 & 24.11 & 27.48 \\
\hline & Total & 100 & 100 & 100 & 100 & 100 & 100 \\
\hline
\end{tabular}

Table 20. Percentage of Electric and Diesel Tube wells By Size Classes in Jalandhar District in 2005-06

\begin{tabular}{|c|c|c|c|c|c|c|c|}
\hline Tehsil & Pump Sets & Marginal & Small & Semi Medium & Medium & Large & All Classes \\
\hline \multirow[b]{3}{*}{ Jalandhar 1} & Electric & 82.76 & 89.32 & 88.24 & 92.79 & 94.69 & 90.95 \\
\hline & Diesel & 17.24 & 10.68 & 11.76 & 7.21 & 5.31 & 9.05 \\
\hline & Total & 100 & 100 & 100 & 100 & 100 & 100 \\
\hline \multirow[b]{3}{*}{ Jalandhar 11} & Electric & 79.55 & 93.64 & 89.66 & 93.72 & 93.37 & 91.73 \\
\hline & Diesel & 20.45 & 6.36 & 10.34 & 6.28 & 6.63 & 8.27 \\
\hline & Total & 100 & 100 & 100 & 100 & 100 & 100 \\
\hline \multirow[b]{3}{*}{ Nakoddar } & Electric & 93.17 & 100.00 & 85.10 & 96.33 & 98.91 & 95.19 \\
\hline & Diesel & 6.83 & 0.00 & 14.90 & 3.67 & 1.09 & 4.81 \\
\hline & Total & 100 & 100 & 100 & 100 & 100 & 100 \\
\hline \multirow[b]{3}{*}{ Shahkot } & Electric & 68.69 & 92.56 & 87.91 & 85.71 & 83.69 & 85.96 \\
\hline & Diesel & 31.31 & 7.44 & 12.09 & 14.29 & 16.31 & 14.04 \\
\hline & Total & 100 & 100 & 100 & 100 & 100 & 100 \\
\hline \multirow[b]{3}{*}{ Phillaur } & Electric & 62.84 & 79.87 & 78.95 & 79.82 & 78.58 & 78.55 \\
\hline & Diesel & 37.16 & 20.13 & 21.05 & 20.18 & 21.42 & 21.45 \\
\hline & Total & 100 & 100 & 100 & 100 & 100 & 100 \\
\hline \multirow{3}{*}{$\begin{array}{c}\text { Jalandhar } \\
\text { District }\end{array}$} & Electric & 75.59 & 90.67 & 85.57 & 88.81 & 88.73 & 87.62 \\
\hline & Diesel & 24.41 & 9.33 & 14.43 & 11.19 & 11.27 & 12.38 \\
\hline & Total & 100 & 100 & 100 & 100 & 100 & 100 \\
\hline
\end{tabular}

In contrast, Jalandhar district had much higher percentage (72.52) of electric pump sets in 1995-96, which represents better status of irrigation infrastructure in Jalandhar (Table 19). The tehsils of Jalandhar also showed lower percentage of electric pump sets with marginal and small farmers compared to medium and large farmers. Despite comparatively lower percentage of electric pump sets with marginal and small farmers in Jalandhar, their percentage of electric pump sets is much higher than large farmers of Mansa district. The percentage share of electric pump sets further increased from 72.52 percent to 87.62 percent in 2005-06 (Table 20 ). The previous two sections provide an understanding of the land holdings and other endowments in the two districts. Now, the next section will analyze the changes in the production and yield of different crops in the two districts.

\section{GROWTH IN PRODUCTION AND YIELD OF VARIOUS CROPS}

The cropping pattern can be understood in the form of change in share of gross cropped area used for different crops, their growth rate and change in production. The agriculture census provides data on area at tehsil and district level, however it is not enough to 
provide complete picture. Therefore, the some of the changes are discussed at Punjab level. In addition, changes at Punjab level also provide a ground for better understanding the district level changes.
The present section first discusses the change at Punjab level, and then moves to district/tehsil level.

Table 21 Average Annual Compound Growth Rate of Production under Various Crop in Punjab

\begin{tabular}{|l|c|c|c|c|c|c|c|c|}
\hline \multicolumn{1}{|c|}{ Years } & Rice & Bajra & Maize & Wheat & Barley & Sugarcane & Potato & Cotton \\
\hline 1970-71 to 1980-81(Period I) & 16.74 & -9.87 & -3.36 & 4.08 & 6.60 & -2.92 & 13.52 & 3.12 \\
\hline 1980-81 to 1990-91(Period II) & 7.24 & -17.22 & -5.90 & 4.71 & -0.67 & 4.37 & -5.13 & 4.95 \\
\hline 1990-91 to 2000-01(Period III) & 3.48 & -8.76 & 3.31 & 2.49 & 0.77 & 2.60 & 9.91 & -4.54 \\
\hline 2001-02 to 2007-08(Period IV) & 1.96 & -3.68 & 1.76 & 0.15 & -8.85 & -2.12 & 5.66 & 10.10 \\
\hline 1970-71 to 2007-08 & 7.64 & -10.51 & -1.35 & 3.06 & 0.00 & 0.65 & 5.76 & 2.74 \\
\hline
\end{tabular}

Table 21 shows that the production of rice grew at the highest rate among all the crops during 1970-71 and 2007-08. Other crops, which had grown significantly during the same period, are wheat, potato and cotton. The growth rate of production of wheat was above 4 percent in period I and period II, and declined period III and period IV. The production of Potato grew at a higher rate in period I (13.52 percent). The production of potato experienced a negative rate of growth (-5.13 percent) during period II, however it again turned positive in period III (9.91 percent). Despite decline in growth rate of production of potato in period IV, the rate of growth

remained high (5.66 percent). Cotton production also had negative growth rate in period III, which changed to high positive growth rate (10.10 percent) in period IV. The major reason for decline in cotton production during 1990s was destruction of cotton crop due to bollworm, which came into control with BT cotton. Other major crops, Bajra, Maize and Barley, either had negative growth rate or did not grow from 1970-71 to 2007-08. Sugarcane showed an increase in production in period II and period III, however the growth rate was relatively low and turned into negative in period IV.

Table 22 Average Annual Compound Growth Rate of Yield under Various Crop in Punjab

\begin{tabular}{|l|c|c|c|c|c|c|c|c|}
\hline \multicolumn{1}{|c|}{ Years } & Rice & Bajra & Maize & Wheat & Barley & Sugarcane & Potato & Cotton \\
\hline 1970-71 to 1980-81 (Period I) & 4.47 & 0.56 & 0.30 & 2.01 & 4.84 & 2.99 & 4.22 & -2.54 \\
\hline 1980-81 to 1990-91 (Period II) & 1.68 & -1.16 & 1.09 & 3.13 & 5.32 & 0.73 & 0.29 & 3.00 \\
\hline 1990-91 to 2000-01 (Period III) & 0.83 & -2.13 & 4.57 & 2.08 & 2.11 & 0.79 & -0.15 & 0.99 \\
\hline 2001-02 to 2007-08 (Period IV) & 1.97 & 0.89 & 2.88 & -0.18 & 0.65 & -0.77 & -0.64 & 5.25 \\
\hline 1970-71 to 2007-08 & 2.25 & -0.58 & 2.14 & 1.91 & 3.42 & 1.06 & 1.04 & 1.35 \\
\hline
\end{tabular}

The growth rate of crop yield shows that the change in production is the result of change in yield as well as area under the crop (Table 22). The table indicates that growth in production of rice was initially due to higher yield as well as increase in land under rice cultivation (which may be the result of shift of land from other crops or high cropping intensity), but in the later phase (period IV) the growth in production is due to yield effect. The increase in yield also contributes significantly in production growth between 1970-

71 and 2000-01. Maize and Barley also experienced considerable growth in yield, nonetheless had negative growth rate of production due to shift in land to other crops (the details of change in area are discussed in next section). Potato has decline in crop yield, which points out that increase in production of the crop is due to relative gain in its area. Growth in production of wheat is mix of rise in area as well yield with a little change in the importance towards the latter.

Table 23 Cropping Intensity by Size Class in Mansa District during 1995-96

\begin{tabular}{|l|c|c|c|c|c|c|}
\hline \multicolumn{1}{|c|}{ Tehsil } & Marginal & Small & Semi Medium & Medium & Large & Total Classes \\
\hline Mansa & 1.94 & 1.93 & 1.97 & 1.93 & 1.86 & 1.92 \\
\hline Budhlada & 1.96 & 1.93 & 1.89 & 1.93 & 1.90 & 1.91 \\
\hline Sardulgarh & 1.98 & 1.96 & 1.97 & 1.92 & 1.70 & 1.85 \\
\hline Mansa District & 1.96 & 1.94 & 1.94 & 1.93 & 1.84 & 1.90 \\
\hline
\end{tabular}

The change in area under a crop is effected by increase in net area sown as well as cropping intensity. Table 23 and 24 points out that the cropping intensity was lower for large farmers in 1995-96 as well as in 2005-06. There was an increase in cropping intensity between 1995-96 and 2005-06. The rise in cropping intensity was visible for all size of holdings. Among the three tehsils, Sardulgarh had relatively lower cropping intensity in both the time periods. The cropping intensity is especially low for large farmers of tehsil, Sardulgarh. Overall, Mansa district has 1.95 cropping intensity, where the value varies between 2.17 and 1.78 .

Table 24 Cropping Intensity by Size Class in Mansa District during 2005-06

\begin{tabular}{|c|c|c|c|c|c|c|}
\hline Tehsil & Marginal & Small & Semi Medium & Medium & Large & Total Classes \\
\hline Mansa & 2.17 & 2.07 & 2.02 & 1.99 & 1.97 & 2.00 \\
\hline Budhlada & 2.03 & 1.98 & 1.97 & 1.97 & 1.94 & 1.97 \\
\hline Sardulgarh & 2.00 & 1.95 & 1.97 & 1.89 & 1.78 & 1.87 \\
\hline Mansa District & 2.08 & 2.01 & 1.99 & 1.96 & 1.90 & 1.95 \\
\hline
\end{tabular}

Jalandhar district also show a trend similar to district of Mansa with large farmers having much lower cropping intensity during 199596 (Table 25). The cropping intensity of large farmers is especially lower in Phillaur. Overall, small, semi medium and medium farmers also have lower cropping intensity compared to marginal farmers, nonetheless marginal, small and semi medium does not 
show any difference in Jalandhar I and Nakodar. Also, the difference among different size classes is negligible in Shahkot. On average, the cropping intensity in Jalandhar district is lower than Mansa district.

Table 25 Cropping Intensity by Size Class in Jalandhar District during 1995-96

\begin{tabular}{|c|c|c|c|c|c|c|}
\hline Tehsil & Marginal & Small & Semi Medium & Medium & Large & Total Classes \\
\hline Jalandhar 1 & 1.97 & 2.03 & 2.04 & 1.90 & 1.75 & 1.91 \\
\hline Jalandhar ll & 2.23 & 1.93 & 1.89 & 1.82 & 1.79 & 1.86 \\
\hline Nakodar & 2.14 & 2.12 & 2.09 & 2.02 & 1.84 & 2.00 \\
\hline Phillaur & 2.02 & 1.68 & 1.84 & 1.77 & 1.09 & 1.54 \\
\hline Shahkot & 1.73 & 1.80 & 1.73 & 1.73 & 1.60 & 1.71 \\
\hline Jalandhar District & 2.03 & 1.87 & 1.90 & 1.84 & 1.48 & 1.76 \\
\hline
\end{tabular}

Table 26 Cropping Intensity by Size Class in Jalandhar District during 2005-06

\begin{tabular}{|c|c|c|c|c|c|c|}
\hline Tehsil & Marginal & Small & Semi Medium & Medium & Large & Total Classes \\
\hline Jalandhar l & 2.01 & 1.92 & 1.93 & 2.01 & 2.04 & 1.99 \\
\hline Jalandhar ll & 2.02 & 1.97 & 1.86 & 1.86 & 1.89 & 1.88 \\
\hline Nakodar & 1.90 & 1.94 & 1.96 & 1.95 & 1.89 & 1.93 \\
\hline Phillaur & 1.94 & 1.96 & 1.92 & 1.89 & 1.89 & 1.90 \\
\hline Shahkot & 1.95 & 1.97 & 1.97 & 1.98 & 1.93 & 1.96 \\
\hline Jalandhar District & 1.97 & 1.95 & 1.93 & 1.93 & 1.91 & 1.92 \\
\hline
\end{tabular}

Jalandhar showed improvement in cropping intensity in 2005-06 (Table 26). The improvement has mainly happened in case of medium and large holdings, and marginal, small and semi medium show either no change or decline in cropping intensity. Shahkot has improved significantly during this period, and the cropping intensity in the tehsil has increased from 1.71 to 1.96 . Another tehsil with considerable change in cropping intensity is Phillaur, where the overall cropping intensity increased from 1.54 to 1.90 , which is mainly the result of increase in cropping intensity of large farmers from merely 1.09 to 1.89 . There is also improvement in the cropping intensity of small farmers in Phillaur. Due to increase in cropping intensity, Jalandhar and Mansa had almost comparable cropping intensity in 2005-06.

\section{TREND AND PATTERN IN AREA UNDER VARIOUS CROPS}

Table 27 Average Annual Compound Growth Rate of Area under Various Crops in Punjab

\begin{tabular}{|c|c|c|c|c|c|c|c|c|}
\hline Years & Rice & Bajra & Maize & Wheat & Barley & Sugarcane & Potato & Cotton \\
\hline $1970-71$ to $1980-81$ & 11.74 & -10.40 & -3.67 & 2.03 & 1.32 & -5.72 & 8.92 & 5.04 \\
\hline $1980-81$ to $1990-91$ & 5.47 & -16.05 & -6.84 & 1.53 & -5.48 & 3.59 & -5.27 & 0.77 \\
\hline $1990-91$ to $2000-01$ & 2.63 & -6.70 & -1.30 & 0.41 & -1.44 & 1.82 & 9.94 & -3.84 \\
\hline 2001-02 to 2007-08 & -0.01 & -5.63 & -1.07 & 0.33 & -9.43 & -1.35 & 6.03 & 3.52 \\
\hline $1970-71$ to $2007-08$ & 5.27 & -10.12 & -3.42 & 1.13 & -3.38 & -0.41 & 4.62 & 1.14 \\
\hline
\end{tabular}

The share of different crops in grossed cropped area showed significant change over the time (Table 28). Rice was the largest gainer in this change, whereas maize, bajra and other minor crops (which comes in the category of 'others') had experienced considerable decline in their share. Wheat and Potato are other two crops that had some increase in their share in gross cropped area.
The analysis in the previous sections has provided a brief sketch of the situation related to land distribution, sources of irrigation, growth of production and yield, and trends in cropping intensity in Punjab particularly in districts of Jalandhar and Mansa. The present section will try to understand the cropping intensity in the context of availability of assets and changes that happened in different variables discussed in previous sections.

Table 27 shows that rice and potato are the two crops that have gained considerably in area under them since 1971-72. The average increase in area under rice between 1970-71 and 2007-08 is 5.27 percent, whereas it is 4.62 percent for potato. The main difference in the growth of area under these two crops is that the area expansion for rice happened before 1990-91, whereas potato started growing at high rate after 1990-91.

Table 28 Percentage Share of Various Crop in Gross Cropped Area in Punjab

\begin{tabular}{|c|c|c|c|c|c|c|c|c|c|}
\hline Years & Rice & Bajra & Maize & Wheat & Sugarcane & Potato & Cotton & Other & Total \\
\hline $1970-71$ & 6.87 & 3.65 & 9.77 & 40.49 & 2.25 & 0.30 & 6.99 & 29.68 & 100 \\
\hline $1980-81$ & 17.49 & 1.02 & 5.65 & 41.58 & 1.05 & 0.59 & 9.60 & 23.03 & 100 \\
\hline $1990-91$ & 26.86 & 0.16 & 2.51 & 43.63 & 1.35 & 0.31 & 9.34 & 15.85 & 100 \\
\hline $2000-01$ & 32.89 & 0.08 & 2.08 & 42.92 & 1.52 & 0.75 & 5.97 & 13.79 & 100 \\
\hline
\end{tabular}




\begin{tabular}{|c|c|c|c|c|c|c|c|c|c|}
\hline & & & & & & & & 0 & 0 \\
\hline \multicolumn{5}{|c|}{$\begin{array}{l}\text { langes that } \\
\text { ere is need } \\
\text { nced since } \\
\text { were three } \\
\text { t occupies } \\
\text { (about } 42 \\
\text { Paddy has } \\
\text { The area } \\
\text { generally } \\
\text { the case of } \\
\text { ain reasons } \\
\text { ater in this } \\
\text { and green } \\
\text { nt of gross }\end{array}$} & \multicolumn{5}{|c|}{$\begin{array}{l}\text { dropped in its share during the same period (Table 30). Though the } \\
\text { increase in share of paddy was considerable in all the tehsils, } \\
\text { nonetheless the tehsils which had larger share of gross cropped area } \\
\text { under paddy still cultivate paddy on larger share of gross cropped } \\
\text { area compared to other tehsils and cotton is still dominant crop in } \\
\text { Sardulgarh area. The reason for shift from cotton to paddy in this } \\
\text { area was mainly because of loss of cotton crop due to bollworm. } \\
\text { However, this decline was limited by the type of soil as well as } \\
\text { availability of water, hence the difference in area under paddy } \\
\text { cultivation in different tehsils. As a result, the increase in area } \\
\text { under paddy was almost same as decline in area under cotton. In } \\
\text { 2000-01, Mansa and Budhlada tehsils had about } 30 \text { percent of gross } \\
\text { cropped area under paddy (compared to } 13.5 \text { and } 19.7 \text { percent in } \\
1995-96 \text {, respectively), and Sardulgarh, which had just } 4.6 \text { percent } \\
\text { area under paddy cultivation in } 1995-96 \text {, was cultivating paddy on } \\
14.17 \text { percent of area in } 2000-01 \text {. }\end{array}$} \\
\hline
\end{tabular}

Table 29 Tehsil-wise Share of Various Crop in Total Gross Cropped Area in Mansa during 1995-96

\begin{tabular}{|c|c|c|c|c|}
\hline Crop & Mansa & Budhlada & Sarulgarh & Total \\
\hline Paddy & 13.5 & 19.7 & 4.6 & 13.9 \\
\hline Wheat & 44.0 & 40.9 & 41.3 & 42.4 \\
\hline Bajra & 0.5 & 0.2 & 0.3 & 0.3 \\
\hline Maize & 0.1 & 0.0 & 0.0 & 0.1 \\
\hline Total Pulses & 1.2 & 0.6 & 1.8 & 1.1 \\
\hline Total Vegetables & 0.0 & 0.0 & 0.0 & 0.0 \\
\hline Cotton & 32.9 & 28.1 & 41.5 & 32.9 \\
\hline Potato & 0.0 & 0.0 & 0.0 & 0 \\
\hline Fodder and Green Manure & 5.0 & 6.2 & 7.1 & 5.9 \\
\hline Other Crop & 2.8 & 4.3 & 3.4 & 3.4 \\
\hline Gross cropped area & 100 & 100 & 100 & 100 \\
\hline
\end{tabular}

Table 30 Tehsil-wise Share of Various Crop in Total Gross Cropped Area in Mansa during 2000-01

\begin{tabular}{|c|c|c|c|c|}
\hline Crop & Mansa & Budhlada & Sarulgarh & Total \\
\hline Paddy & 28.19 & 31.53 & 14.17 & 25.19 \\
\hline Wheat & 44.61 & 43.14 & 43.42 & 43.82 \\
\hline Bajra & 0.09 & 0.19 & 0.34 & 0.19 \\
\hline Maize & 0.03 & 0.11 & 0.09 & 0.07 \\
\hline Total Pulses & 0.50 & 0.44 & 0.39 & 0.45 \\
\hline Total Vegetables & 0.30 & 0.13 & 0.15 & 0.20 \\
\hline Cotton & 17.43 & 14.73 & 28.63 & 19.81 \\
\hline Potato & 0.23 & 0.01 & 0.02 & 0.10 \\
\hline Fodder and Green Manure & 5.11 & 5.48 & 5.81 & 5.42 \\
\hline Other Crop & 3.7 & 4.3 & 7.0 & 4.8 \\
\hline Gross cropped area & 100 & 100 & 100 & 100 \\
\hline
\end{tabular}

The cropping pattern in Mansa district remained almost same in 2005-06 (Table 31). The minor change that happened is a little shift in area under paddy to cotton and pulses in Budhlada. One of the

reasons behind this trend reversal is reduced effect of bollworm due to BT cotton.

Table 31 Tehsil-wise Share of Various Crop in Total Gross Cropped Area in Mansa during 2005-06

\begin{tabular}{|l|c|c|c|}
\hline \multicolumn{1}{|c|}{ Crop } & Mansa & Budhlada & Sarulgarh \\
\hline Paddy & 27.37 & 21.29 & 13.82 \\
\hline Wheat & 43.21 & 43.19 & 44.42 \\
\hline Bajra & 0.25 & 1.42 & 0.77 \\
\hline Maize & 0.21 & 0.10 & 0.65 \\
\hline
\end{tabular}




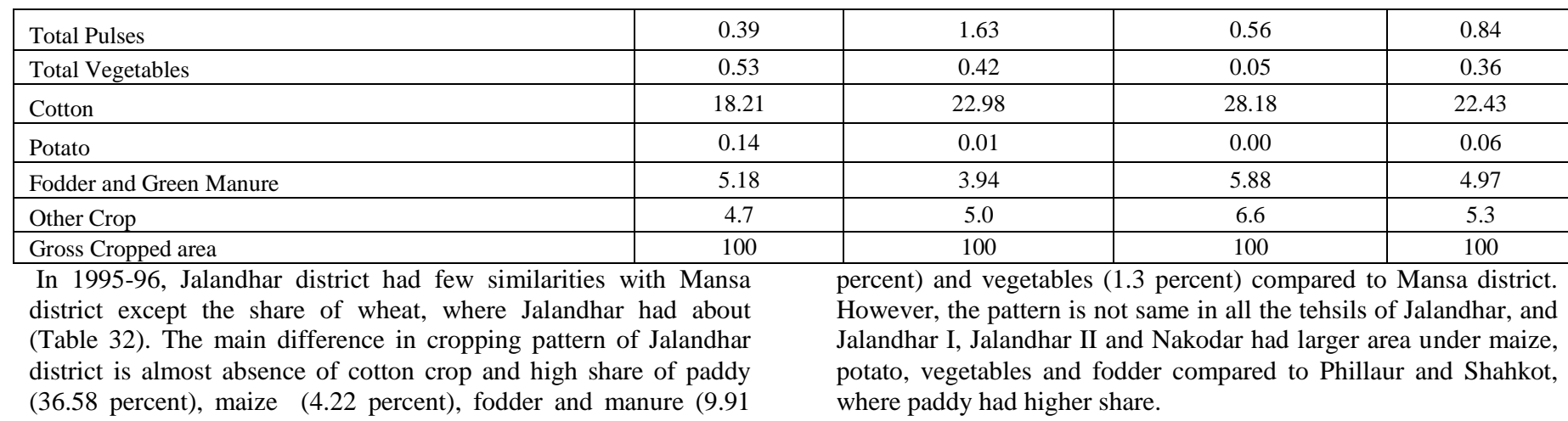

Table 32 Tehsil-wise Share of Various Crop in Total Gross Cropped Area in Jalandhar during $1995-96$

\begin{tabular}{|c|c|c|c|c|c|c|}
\hline Crop & Jalandhar 1 & Jalandhar 11 & Nakodar & Phillaur & Shahkot & Total \\
\hline Paddy & 31.32 & 36.07 & 34.23 & 38.55 & 41.17 & 36.58 \\
\hline Wheat & 34.41 & 36.16 & 37.86 & 40.48 & 40.54 & 38.15 \\
\hline Bajra & 0.31 & 0.00 & 0.00 & 0.00 & 0.03 & 0.05 \\
\hline Maize & 6.54 & 3.80 & 5.35 & 3.31 & 3.02 & 4.22 \\
\hline Total Pulses & 0.34 & 0.02 & 0.05 & 0.89 & 0.54 & 0.39 \\
\hline Total Vegetables & 1.49 & 2.59 & 1.66 & 0.11 & 0.91 & 1.30 \\
\hline Cotton & 0.08 & 0.00 & 0.49 & 0.01 & 0.23 & 0.15 \\
\hline Potato & 1.07 & 1.73 & 1.55 & 0.04 & 0.42 & 0.92 \\
\hline $\begin{array}{l}\text { Fodder \& Green } \\
\text { Manure }\end{array}$ & 13.57 & 10.44 & 12.07 & 7.21 & 8.06 & 9.91 \\
\hline Other Crop & 11.93 & 10.93 & 8.29 & 9.45 & 5.50 & 9.27 \\
\hline Gross Cropped area & 100 & 100 & 100 & 100 & 100 & 100 \\
\hline
\end{tabular}

Minor changes were observed in Jalandhar in 2000-01, where vegetables, potato, wheat and paddy gained in share and share of maize and other crops declined (Table 33). Potato and vegetables, further, had an increasing in its share in 2005-06 (Table 34). In addition, maize and pulses also showed an improvement in its share. Wheat and paddy, once again, made about 80 percent of the gross cropped area. The trend also points out the higher share of wheat and paddy in Phillaur and Shahkot, whereas Jalandhar I, Jalandhar II and Nakodar had larger share of gross cropped area under vegetables, maize, potato and fodder.

Table 33 Tehsil-wise Share of Various Crop in Total Gross Cropped Area in Jalandhar during 2000-01

\begin{tabular}{|c|c|c|c|c|c|c|}
\hline \multirow{2}{*}{ Crop } & \multirow{2}{*}{ Jalandhar 1} & \multirow{2}{*}{ Jalandhar 11} & & \multirow[b]{2}{*}{ Total } \\
\hline & & & Nakodar & Phillaur & Shahkot & \\
\hline Paddy & 33.35 & 36.88 & 35.05 & 39.03 & 42.83 & 37.80 \\
\hline Wheat & 39.24 & 38.50 & 38.66 & 40.91 & 43.37 & 40.22 \\
\hline Bajra & 0.10 & 0.05 & 0.03 & 0.67 & 0.11 & 0.25 \\
\hline Maize & 5.64 & 2.99 & 2.43 & 2.80 & 1.88 & 3.00 \\
\hline Total Pulses & 0.27 & 0.18 & 0.27 & 0.51 & 0.52 & 0.37 \\
\hline Total Vegetables & 4.71 & 4.13 & 3.90 & 0.48 & 1.36 & 2.59 \\
\hline Cotton & 0.00 & 0.00 & 0.08 & 0.08 & 0.00 & 0.04 \\
\hline Potato & 3.77 & 3.75 & 3.18 & 0.37 & 1.16 & 2.19 \\
\hline $\begin{array}{l}\text { Fodder \& Green } \\
\text { Manure }\end{array}$ & 11.89 & 11.80 & 13.91 & 6.80 & 8.03 & 10.01 \\
\hline Other Crop & 4.80 & 5.49 & 5.66 & 8.74 & 1.91 & 5.72 \\
\hline Gross cropped area & 100.00 & 100.00 & 100.00 & 100.00 & 100.00 & 100.00 \\
\hline
\end{tabular}

Table 34 Tehsil-wise Share of Various Crop in Total Gross Cropped Area in Jalandhar during 2005-06

\begin{tabular}{|l|c|c|c|c|c|c|}
\hline \multicolumn{1}{|c|}{ Crop } & Jalandhar 1 & Jalandhar ll & Nakodar & Phillaur & Shahkot & Total \\
\hline Paddy & 34.97 & 37.19 & 40.97 & 41.41 & 39.58 & 39.34 \\
\hline Wheat & 38.08 & 39.89 & 40.64 & 43.29 & 40.85 & 41.00 \\
\hline Bajra & 0.10 & 0.04 & 0.21 & 0.13 & 0.22 & 0.14 \\
\hline Maize & 5.20 & 3.17 & 3.06 & 3.13 & 3.40 & 3.46 \\
\hline
\end{tabular}




\begin{tabular}{|l|c|c|c|c|c|c|}
\hline Total Pulses & 0.58 & 0.24 & 1.00 & 0.77 & 1.29 & 0.79 \\
\hline Total Vegetables & 7.06 & 4.48 & 2.20 & 0.91 & 6.00 & 3.61 \\
\hline Cotton & 0.00 & 0.05 & 0.12 & 0.05 & 0.00 & 0.05 \\
\hline Potato & 6.79 & 3.68 & 1.85 & 0.87 & 4.96 & 3.16 \\
\hline $\begin{array}{l}\text { Fodder \& Green } \\
\text { Manure }\end{array}$ & 8.15 & 6.37 & 4.92 & 5.09 & 5.58 & 5.80 \\
\hline Other Crop & 5.86 & 8.58 & 6.88 & 5.22 & 3.08 & 5.80 \\
\hline Gross cropped area & 100 & 100 & 100 & 100 & 100 & 100 \\
\hline
\end{tabular}

Table 35 Size Class wise Share of Various Crop in Total Gross Cropped Area in Mansa during 1995-96

\begin{tabular}{|l|c|c|c|c|c|c|}
\hline \multicolumn{1}{|c|}{ Crop } & Marginal & Small & Semi Medium & Medium & Large & Total Classes \\
\hline Paddy & 4.39 & 9.23 & 12.73 & 13.86 & 15.53 & 13.90 \\
\hline Wheat & 44.48 & 42.23 & 41.90 & 42.60 & 42.28 & 42.38 \\
\hline Bajra & 0.46 & 0.09 & 0.03 & 0.33 & 0.48 & 0.32 \\
\hline Maize & 0.04 & 0.00 & 0.05 & 0.04 & 0.16 & 0.08 \\
\hline Total Pulses & 0.48 & 0.29 & 0.48 & 0.96 & 1.68 & 1.08 \\
\hline Total Vegetables & 0.11 & 0.01 & 0.00 & 0.02 & 0.05 & 0.03 \\
\hline Cotton & 41.09 & 37.06 & 34.25 & 32.85 & 31.47 & 32.92 \\
\hline Potato & 0.00 & 0.00 & 0.00 & 0.00 & 0.00 & 0.00 \\
\hline Fodder and Green & 7.89 & 9.63 & 8.46 & 2.79 & 4.45 & 4.70 \\
Manure & 1.06 & 1.46 & 100 & 6.56 & 3.89 & 4.59 \\
\hline Other Crop & 100 & 100 & 100 & 100 & 100 & 100 \\
\hline Gross cropped area & & & & & \\
\hline
\end{tabular}

The data on cropping pattern according to size of operation holding shows a change in pattern as the size of operational holding grows in Mansa district in 1995-96 (Table 35). Wheat is the main crop among all the size classes. The main difference among different size classes is in the case of paddy, cotton, fodder and pulses. Larger farmers had more area under paddy and pulses, whereas marginal and smaller ones were growing more cotton and fodder.

Table 36 shows that the pattern almost continued in Mansa district in 2000-01, and cotton made a larger share of gross cropped area for marginal and small farmers and despite increase in share of paddy for marginal and small farmers, large farmers had larger share of gross cropped area under paddy. The difference in share of fodder had lowered, and it is small and medium farmers that had larger share. The area under pulses also showed decline for all classes, even though larger farmers had larger share of their gross cropped area under it. The data again showed a similar pattern for Mansa in 2005-06 except that difference among different size classes in fodder almost disappeared (Table 37).

Table 36 Size Class wise Share of Various Crop in Total Gross Cropped Area in Mansa during 2000-01

\begin{tabular}{|l|c|c|c|c|c|c|}
\hline \multicolumn{1}{|c|}{ Crop } & Marginal & Small & Semi Medium & Medium & Large & Total Classes \\
\hline Paddy & 12.59 & 18.11 & 21.85 & 26.83 & 26.14 & 25.19 \\
\hline Wheat & 46.97 & 44.83 & 44.72 & 43.98 & 42.84 & 43.82 \\
\hline Bajra & 0.05 & 0.11 & 0.13 & 0.22 & 0.21 & 0.19 \\
\hline Maize & 0.00 & 0.09 & 0.04 & 0.13 & 0.02 & 0.07 \\
\hline Total Pulses & 0.00 & 0.18 & 0.11 & 0.53 & 0.58 & 0.34 \\
\hline Total Vegetables & 0.09 & 0.06 & 0.05 & 0.18 & 17.24 & 0.20 \\
\hline Cotton & 33.77 & 27.47 & 23.45 & 17.70 & 19.24 & 19.81 \\
\hline Potato & 0.00 & 0.01 & 0.02 & 0.09 & 0.18 & 0.10 \\
\hline $\begin{array}{l}\text { Fodder and Green } \\
\text { Manure }\end{array}$ & 5.42 & 7.73 & 7.10 & 5.42 & 4.20 & 5.42 \\
\hline Other Crop & 1.12 & 1.42 & 2.57 & 5.01 & 6.44 & \\
\hline Gross cropped area & 100 & 100 & 100 & 100 & 100 & \\
\hline
\end{tabular}

Table 37 Size Class wise Share of Various Crop in Total Gross Cropped Area in Mansa during 2005-06

\begin{tabular}{|l|c|c|c|c|c|c|}
\hline \multicolumn{1}{|c|}{ Crop } & Marginal & Small & Semi Medium & Medium & Large & Total Classes \\
\hline Paddy & 9.81 & 15.36 & 18.72 & 22.67 & 24.11 & 21.77 \\
\hline Wheat & 45.92 & 44.85 & 44.37 & 42.96 & 43.51 & 43.53 \\
\hline Bajra & 0.00 & 0.04 & 0.32 & 0.63 & 1.03 & 0.65 \\
\hline Maize & 0.02 & 0.01 & 0.09 & 0.18 & 0.26 & 0.17 \\
\hline Total Pulses & 0.15 & 0.43 & 0.94 & 0.83 & 0.88 & 0.84 \\
\hline
\end{tabular}




\begin{tabular}{|l|c|c|c|c|c|c|}
\hline Total Vegetables & 0.00 & 0.05 & 0.21 & 0.37 & 0.54 & 0.36 \\
\hline Cotton & 36.19 & 30.12 & 26.28 & 21.26 & 19.64 & 22.42 \\
\hline Potato & 0.00 & 0.00 & 0.02 & 0.06 & 0.09 & 0.06 \\
\hline $\begin{array}{l}\text { Fodder and Green } \\
\text { Manure }\end{array}$ & 3.20 & 5.63 & 5.45 & 5.04 & 4.51 & \\
\hline Other Crop & 4.71 & 3.50 & 3.62 & 6.07 & 5.51 & 5.97 \\
\hline Gross cropped area & 100 & 100 & 100 & 100 & 100 & 5.29 \\
\hline
\end{tabular}

Jalandhar also showed larger area under paddy, potato, vegetables and other minor crops, which were given under other crops, in case of medium and large holdings (Table 38). On the other hand,

marginal and small farmers devoted larger share of gross cropped area to maize and fodder.

Table 38 Size Class wise Share of Various Crop in Total Gross Cropped Area in Jalandhar during 1995-96

\begin{tabular}{|c|c|c|c|c|c|c|}
\hline Crop & Marginal & Small & Semi Medium & Medium & Large & Total Classes \\
\hline Paddy & 29.37 & 30.11 & 35.80 & 37.93 & 38.82 & 36.58 \\
\hline Wheat & 38.34 & 37.72 & 35.97 & 38.98 & 35.95 & 37.43 \\
\hline Bajra & 0.10 & 0.12 & 0.07 & 0.05 & 0.00 & 0.05 \\
\hline Maize & 5.57 & 7.86 & 4.50 & 3.89 & 3.10 & 4.22 \\
\hline Total Pulses & 0.08 & 0.71 & 0.40 & 0.39 & 0.38 & 0.39 \\
\hline Total Vegetables & 0.16 & 1.15 & 0.90 & 1.03 & 2.47 & 1.30 \\
\hline Cotton & 0.02 & 0.13 & 0.19 & 0.15 & 0.14 & 0.15 \\
\hline Potato & 0.05 & 0.34 & 0.60 & 0.72 & 1.92 & 0.91 \\
\hline $\begin{array}{l}\text { Fodder and Green } \\
\text { Manure }\end{array}$ & 25.42 & 16.38 & 11.76 & 8.05 & 5.22 & 9.91 \\
\hline Other Crops & 0.94 & 5.81 & 10.42 & 9.53 & 13.92 & 9.99 \\
\hline Gross cropped area & 100 & 100 & 100 & 100 & 100 & 100 \\
\hline
\end{tabular}

Table 39 Size Class wise Share of Various Crop in Total Gross Cropped Area in Jalandhar during 2000-01

\begin{tabular}{|l|c|c|c|c|c|c|}
\hline \multicolumn{1}{|c|}{ Crop } & Marginal & Small & Semi Medium & Medium & Large & Total Classes \\
\hline Paddy & 30.07 & 36.53 & 37.58 & 38.85 & 38.50 & 37.80 \\
\hline Wheat & 41.30 & 41.44 & 41.25 & 40.34 & 38.55 & 40.22 \\
\hline Bajra & 0.36 & 0.10 & 0.16 & 0.26 & 0.31 & 0.25 \\
\hline Maize & 7.96 & 4.33 & 3.51 & 2.48 & 1.85 & 3.00 \\
\hline Total Pulses & 0.22 & 0.20 & 0.33 & 0.39 & 0.45 & 0.37 \\
\hline Total Vegetables & 0.50 & 0.74 & 0.90 & 2.22 & 5.58 & 2.58 \\
\hline Cotton & 0.00 & 0.01 & 0.04 & 0.03 & 0.06 & 0.04 \\
\hline Potato & 0.26 & 0.18 & 0.56 & 1.92 & 5.05 & 2.19 \\
\hline $\begin{array}{l}\text { Fodder and Green } \\
\text { Manure }\end{array}$ & 18.51 & 14.48 & 12.21 & & & \\
\hline Other Crop & 1.08 & 2.16 & 4.02 & 6.41 & 5.80 & \\
\hline Gross cropped area & 100 & 100 & 100 & 100 & 100 & \\
\hline
\end{tabular}

Table 40 Size Class wise Share of Various Crop in Total Gross Cropped Area in Jalandhar during 2005-06

\begin{tabular}{|c|c|c|c|c|c|c|}
\hline Crop & Marginal & Small & Semi Medium & Medium & Large & Total Classes \\
\hline Paddy & 32.58 & 37.59 & 38.67 & 39.69 & 39.81 & 39.34 \\
\hline Wheat & 41.42 & 42.43 & 41.61 & 41.27 & 40.10 & 41.00 \\
\hline Bajra & 0.40 & 0.15 & 0.16 & 0.13 & 0.14 & 0.14 \\
\hline Maize & 9.69 & 5.41 & 4.01 & 3.29 & 2.83 & 3.46 \\
\hline Total Pulses & 0.40 & 0.54 & 0.65 & 0.73 & 1.01 & 0.79 \\
\hline Total Vegetables & 1.01 & 0.95 & 2.51 & 3.55 & 4.80 & 3.61 \\
\hline Cotton & 0.02 & 0.00 & 0.06 & 0.03 & 0.07 & 0.05 \\
\hline Potato & 0.69 & 0.59 & 2.06 & 3.12 & 4.31 & 3.16 \\
\hline $\begin{array}{l}\text { Fodder and Green } \\
\text { Manure }\end{array}$ & 12.95 & 10.98 & 7.89 & 5.72 & 3.67 & 5.80 \\
\hline Other Crop & 1.53 & 1.96 & 4.44 & 5.58 & 7.58 & 5.80 \\
\hline
\end{tabular}




Gross cropped area
The pattern became more pronounced with large and medium
farmers, further, increasing the land under vegetables and potato,
and lowering the area under maize in Jalandhar in $2000-01$ (Table
39). There is also some decline in share of fodder in marginal and
small holdings. Table 40 showed continuity of the pattern, observed
in the previous time periods, in 2005-06, with a small increase in
share of maize for marginal holdings, and decline in share of fodder
for marginal, small and semi-medium holdings.

\section{SUMMARY AND CONCLUSION}

The medium and semi-medium size holdings had the highest share of operational holdings in Mansa and Jalandhar district, accounting for more than 60 percent of total operational holdings in 2005-06. Jalandhar, in comparison to Mansa district, had large share of marginal holdings in 2000-01, which declined considerable by 2005-06. Medium and large farmers also control about 75 percent of the land in Mansa and Jalandhar during 2005-06. A significant increase is reported in the share of area operated by medium and large farmers in Jalandhar, which went up from about 60 percent in 2000-01 to more than 70 percent of the gross cropped area in 200506 . The above two indicators show a convergence between the two districts over time. Nonetheless, Mansa and Jalandhar differ considerable in source of irrigation, where Mansa depend highly on canal water in comparison to Jalandhar which almost fully reliant on tubewell irrigation. Also, about 75 percent of the farmers in Mansa use diesel pump set, whereas it is just 11 percent for Jalandhar district. The higher share of electric pump set among medium and large size farmers in Mansa district also suggests that the availability of electric connection is biased towards the large holdings.

Rice, potato, wheat and cotton are four crops with positive growth rate between 1970-71 and 2007-08 in Punjab, which some changes in growth rate of the crops. The growth in the production is due to increase in yield for rice and wheat, but increase in area under crop (both due to shift of area from other crops as well as increase in cropping intensity) played major role for other two crops. Maize and barley are two crops which did not experience any growth in production (in fact, maize had negative growth rate) despite the increase in yield per hectare. This shows decline in area under the two crops. Bajra, maize and barley are three crops which are most affected by negative growth rate in area, and rice is the largest gainer in area. The area under rice in Punjab increased from mer4ely 6 percent in 1970-71 to 33 percent in 2007-08.

The data of Mansa and Jalandhar district shows that wheat is the dominant crops in both the districts. Second major crop in Mansa is cotton and paddy, whereas it is paddy for Jalandhar. Over time, Mansa is showing a shift from cotton towards paddy crop, the shift is high among medium and large farmers. The shift is relatively small in tehsils where paddy cultivation is difficult due to soil conditions. Jalandhar, which is almost entirely, cultivating wheat and paddy, show a little presence of maize, potato, fodder and other commercial crops. However, the area under maize, potato, fodder and pulses etc. is high among marginal and small farmers, which may be doing it due to higher returns and higher labour requirement (which is often easily available in marginal and small households in the form of family labour).

The present study clears us the present situation of the two districts (as well as of Punjab). The two districts indicate towards a trend, where marginal and small holding may not remain viable unless, some alternatives which provide high returns per acre with considerable income security are provided to the people. Though,

\begin{tabular}{|l|l|l|l}
100 & 100 & 100 & 100
\end{tabular}

there is a trend among marginal and small farmers to cultivate labour intensive commercial crops (which is fit for cultivation on small holdings due to higher labour requirement, and lower use of machinery) but this may not succeed if there is a high risk due to nature of market of weak institutions. However, there is further need to explore the issues with micro level data.

\section{REFERENCE}

1. Sen, A.K. (1962), "An Aspect of Indian Agriculture", Economic Weekly, 14, pp: 243-246.

2. Dantwala, M.L. (1961), "Agrian Structure in 12 districts", Economic and Political Weekly (special number).

3. Berry, R. A., and W. R. Cline (1979), "Agrarian Structure and Productivity in Developing Countries", Baltimore: John Hopkins Press.

4. Sanyal, S.K. (1969), "Size of Holding and some factors related to production", Economic and Political Weekly, IX No. 33, August 16.

5. Rudra, Ashok and Amartya Sen (1980), "Farm Size and Labour Use: Analysis and Policy", Economic and Political Weekly, Vol. 15, February.

6. Soni, R.N. and O.P. Bajaj (1983), "Problems of Small Farm: A Study (Sponsored by I.C.A.R) conducted by Dept. of Statistics, Punjab University, Chandigarh.

7. Bhalla, G.S. and G.K. Chadha (1983) "Green Revolution and the small Peasants", New Delhi: Concept Publishing Co.

8. Shergill, H.S( ), "Wheat and Paddy Cultivation and the Question of Optimal Cropping Pattern For Punjab".:www.global.ucsb.edu/punjab/12.2_Shergill.

9. Singh, Iqbal (1989), "Reverse Tenancy in Punjab Agriculture impact of Technological Change", " Economic and Political Weekly, vol 24, No. 25, jun. 24.

10. Government of India (2001) Agricultural Census 2000-01, Ministry of Agriculture, New Delhi. [URL: http://agcensus.dacnet.nic.in/] accessed on 5 August 2012.

11. Government of India (1996) Agricultural Census 1995-96, Ministry of Agriculture, New Delhi. [URL:

http://agcensus.dacnet.nic.in/] accessed on 5 August 2012.

12. Government of India (2006) Agricultural Census 2005-06, Ministry of Agriculture, New Delhi. [URL: http://agcensus.dacnet.nic.in/] accessed on 5 August 2012 